\title{
MENGAMATI KESELAMATAN PENUMPANG ANGKUTAN SUNGAI DAN DANAU
}

\author{
Budi Hartanto Susilo ${ }^{1}$, Petrus Teguh Esha ${ }^{2}$ \\ ${ }^{1}$ Dosen Jurusan Teknik Sipil, Fakultas Teknik, Universitas Kristen Maranatha \\ Jl. Prof. drg. Suria Sumantri, MPH., No. 65, Bandung, 40164 \\ Email: budiharsus@yahoo.com \\ ${ }^{2}$ Staf Teknik, Harandass Consultant, Jl. dr. Slamet No.11 Bandung 40131 \\ Email: esha_stuff@yahoo.com
}

\begin{abstract}
ABSTRAK
Tingkat kecelakaan angkutan sungai dan danau di Indonesia saat ini masih cukup tinggi. Hal ini disebabkan karena kurangnya tingkat kelaikan angkutan yang di gunakan dan faktor manusia yang seringkali mengabaikan standar keselamatan yang ada. Selain itu sosialisasi dalam kesadaran berkesalamatan dalam transportasi sangat minim adanya yang berakibat kelalaian terhadap pengguna angkutan sungai dan darat. Dari hasil pengamatan di provinsi Sumatera Utara, Sumatera Selatan, Kalimantan Selatan, dan Bali, ternyata tiap wilayah telah mempunyai Perda dan peraturan lokal untuk menanggulangi bahaya kecelakaan angkutan sungai dan danau dengan istilah teknik yang berbeda, kedalaman dan keluasan peraturan termasuk perizinan yang berbeda pula. Di sisi yang lain mempunyai orientasi yang sama bahwa dalam hal perizinan angkutan sungai dan danau (ASD) merupakan PAD (Pendapatan Asli Daerah) sehingga ketegasan dalam penerapan keselamatan ASD menjadi lemah, seperti penggunaan baju pelampung, alat navigasi, dan lain-lain.
\end{abstract}

Kata kunci: keselamatan, angkutan sungai dan danau, manajemen, sarana, prasarana, SDM, penanganan.

\section{PENDAHULUAN}

Tingkat kecelakaan lalu lintas dan angkutan sungai dan danau di Indonesia saat ini masih cukup tinggi. Hal ini disebabkan karena kurangnya tingkat kelaikan angkutan yang di gunakan dan faktor manusia yang seringkali mengabaikan standar keselamatan yang ada. Selain itu sosialisasi dalam kesadaran berkesalamatan dalam transportasi sangat minim adanya yang berakibat kelalaian terhadap pengguna angkutan sungai dan darat. Padahal kerugian akibat kecelakaan tersebut terkadang dirasakan teramat besar khususnya bagi para korban kecelakaan tersebut baik kerugian materi maupun kerugian jiwa.

Dengan semakin tingginya intensitas dan curah hujan, serta tingginya arus air mengakibatkan terganggunya aktivitas pelayaran kapal akibat cuaca buruk, perubahan arah angin, dan gelombang yang tinggi. Kondisi cuaca yang tidak memungkinkan, termasuk perubahan arah angin dapat menghambat aktivitas pelayaran dan mengganggu jadwal operasional kapal. Peningkatan resiko terjadinya kecelakaan kapal akan meningkat akibat kondisi cuaca, angin, 
gelombang air, dan curah hujan yang tidak bersahabat. Semakin seringnya kasus kecelakaan kapal yang terjadi akhir-akhir ini merupakan salah satu bukti nyata bahwa perubahan iklim telah berdampak negatif terhadap sektor transportasi angkutan sungai dan danau (ASD) dan berakibat fatal.

\section{TINJAUAN PUSTAKA}

Ada beberapa kebijakan yang mengatur tentang keselamatan angkutan sungai dan danau, antara lain:

1) Undang-Undang Nomor 17 Tahun 2008 Tentang Pelayaran

2) Peraturan Pemerintah Nomor 20 Tahun 2010 Tentang Angkutan di Perairan

3) Peraturan Pemerintah Nomor 5 Tahun 2010 Tentang Kenavigasian

4) Peraturan Pemerintah Nomor 38 Tahun 2007 Tentang Pembagian Urusan Pemerintahan Antara Pemerintah, Pemerintahan Daerah Provinsi, Dan Pemerintahan Daerah Kab/Kota

\section{STUDI KASUS}

\subsection{Data Kecelakan Angkutan Sungai dan Danau}

Dari hasil kunjungan ke Dinas Perhubungan provinsi Sumatera Utara, Sumatera Selatan, Kalimantan Selatan, dan Bali, hanya Dinas Perhubungan Provinsi Sumatera Selatan yang memiliki data informasi kecelakaan angkutan sungai dan danau. Berdasarkan informasi yang diperoleh dari Dinas Perhubungan Provinsi Sumatera Selatan, telah cukup banyak terjadi kecelakaan angkutan sungai dan danau di provinsi Sumatera Selatan seperti terlihat pada Tabel 1.

Tabel 1. Data Kecelakaan Angkutan Sungai di Provinsi Sumatera

Selatan Tahun $2008-2012$

\begin{tabular}{|l|c|c|c|c|c|}
\hline \multicolumn{1}{|c|}{ Tahun } & $\mathbf{2 0 0 8}$ & $\mathbf{2 0 0 9}$ & $\mathbf{2 0 1 0}$ & $\mathbf{2 0 1 1}$ & $\mathbf{2 0 1 2}$ \\
\hline Jumlah Kecelakaan & 2.026 & 2.218 & 2.494 & 3.111 & 2.806 \\
\hline Meninggal Dunia & 1.067 & 1.051 & 1.057 & 1.332 & 1.232 \\
\hline Luka Berat & 1.312 & 1.470 & 1.536 & 1.676 & 1.716 \\
\hline Luka Ringan & 1.363 & 1.725 & 2.146 & 2.481 & 2.111 \\
\hline $\begin{array}{l}\text { Kerugian Materill } \\
\text { jutaan rupiah) }\end{array}$ & 12.197 & 10.368 & 14.821 & 34.419 & 16.440 \\
\hline
\end{tabular}


Sumber: Dinas Perhubungan Provinsi Sumatera Selatan, 2012.

\subsection{Fasilitas Alat-Alat Penyelamat}

Dari hasil pengamatan di provinsi Sumatera Utara, Sumatera Selatan, Kalimantan Selatan, dan Bali, fasilitas alat-alat penyelamat seperti ban pelampung, baju pelampung, tali temali, dan sekoci tidak sepenuhnya tersedia di dalam kapal. Terlebih di Danau Batur, Bali, baju pelampung di berserakan begitu saja tidak digunakan (lihat Gambar 1). Padahal di keempat provinsi tersebut sudah ada standar perlengkapan keselamatan kapal angkutan sungai dan danau, tetapi pemeriksaan perlengkapan keselamatan tersebut belum dilakukan secara maksimal.

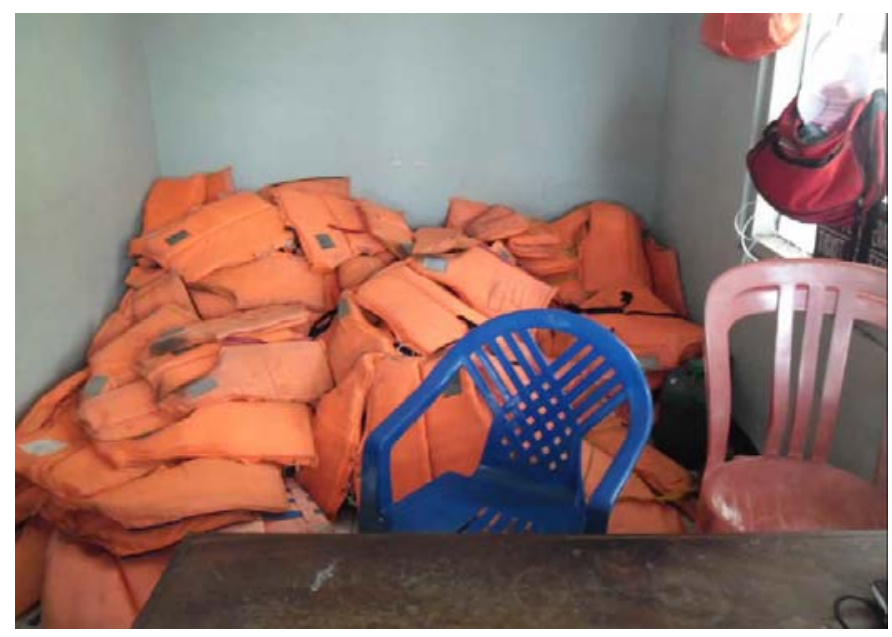

\section{Gambar 1. Baju pelampung berserakan di pos petugas dermaga Danau} Batur, Bali.

\subsection{Kelayakan Kapal}

Menurut informasi dari Dinas Perhubungan di masing-masing daerah, kapal angkutan sungai dan danau yang beroperasi sudah memenuhi standar kelaikan dan mengikuti prosedur serta manual uji berkala dan uji tipe. Akan tetapi tidak adanya standar yang mengatur masa layan kapal, sehingga kapal yang sudah berumur lama masih bisa beroperasi, tentunya hal ini sangat membahayakan penumpang. 


\subsection{Awak Kapal}

Dinas Perhubungan Provinsi Sumatera Selatan telah menetapkan / memberlakukan standar untuk awak kapal khususnya bagi juru mudi yaitu berupa STK (Surat Tanda Kecakapan) atau Surat Keterangan Kecakapan Kapal Pedalaman (SKKKP)., seperti tampak pada Gambar 2. Meski sudah ada surat keterangan bagi juru mudi tersebut, kenyataannya masih ada juru mudi yang belum cukup umur. Hal ini tentunya membahayakan keselamatan penumpang kapal.

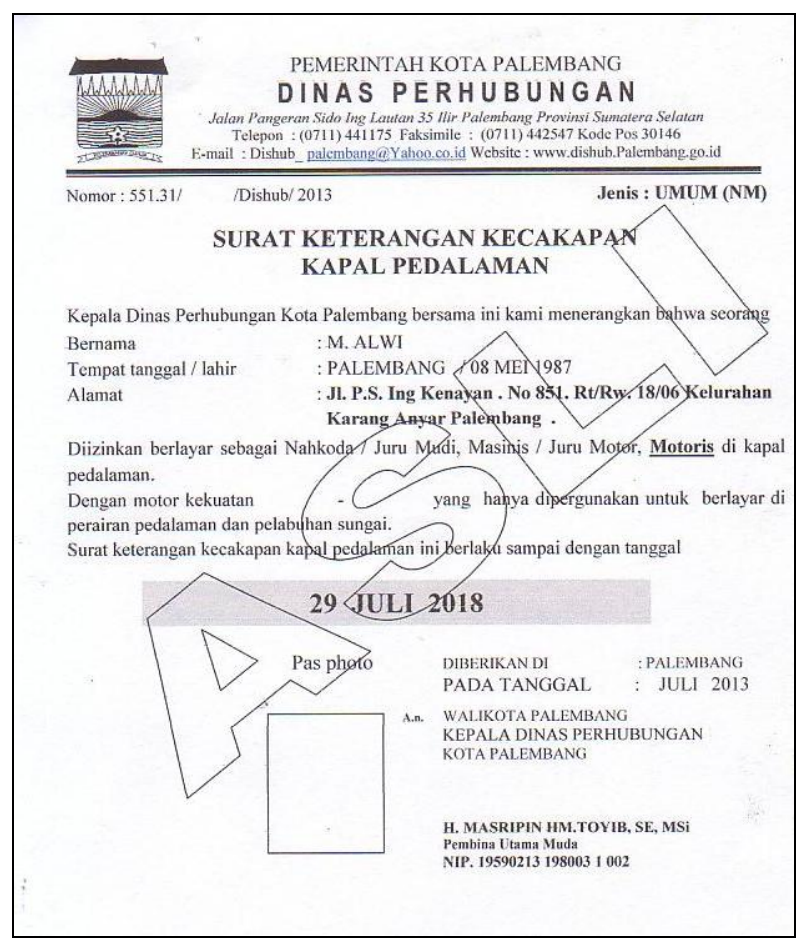

Gambar 2. Surat Keterangan Kecakapan Kapal Pedalaman (SKKKP).

\subsection{Dermaga}

Kondisi dermaga tentunya diperhatikan juga demi keselamatan penumpang. Kondisi dermaga yang rusak sangat membahayakan penumpang, seperti yang ada di Danau Batur, Bali (lihat Gambar 3.) 


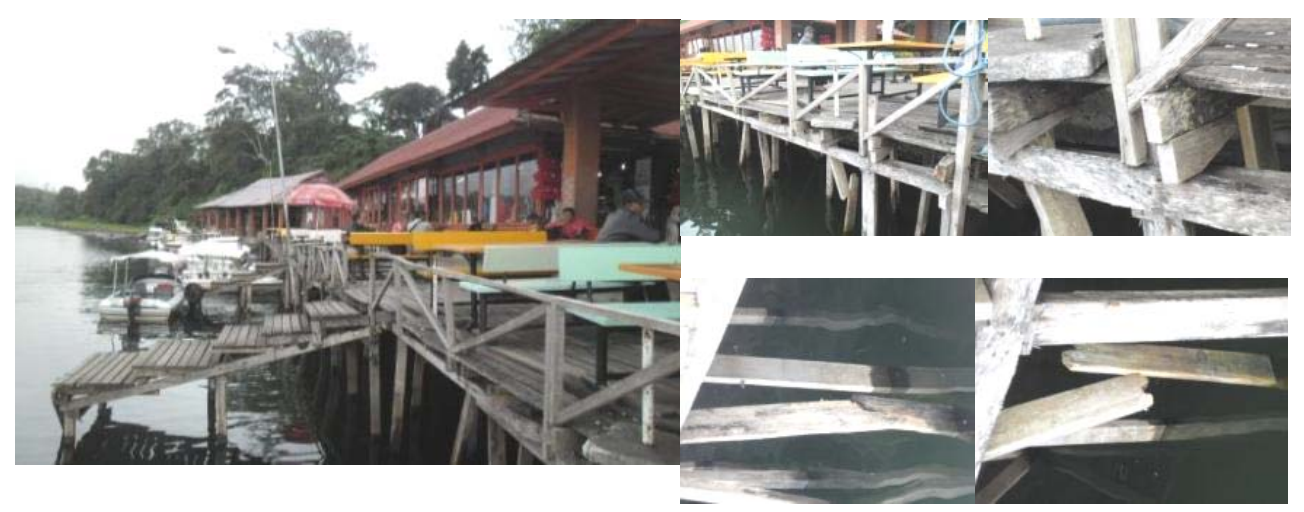

Gambar 3. Kondisi dermaga di Danau Batur, Bali.

Dermaga lainnya di Bali, yaitu dermaga kayu di Desa Kedisan sudah kurang memadai untuk menaikkan dan menurunkan penumpang (lihat Gambar 4). Apalagi Dermaga Kedisan merupakan dermaga induk dan merupakan pintu gerbang menuju objek wisata Desa Trunyan (ke kuburan). Oleh karena itu perlu mendapatkan perhatian untuk diperbaiki seiring dengan penataan kawasan dermaga untuk menunjang objek kepariwisataan. Begitu juga dengan dermaga beton yang ada di Desa Trunyan kondisinya saat ini dengan pasangnya air danau sudah berada di bawah permukaan air sehingga tidak dapat berfungsi sebagaimana mestinya (lihat Gambar 5).

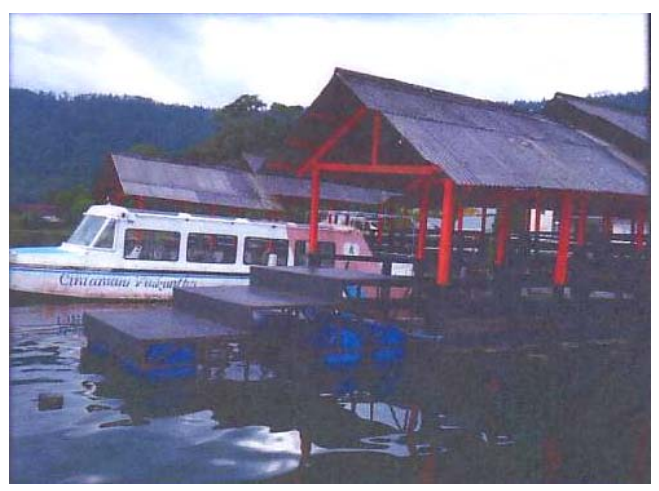

Gambar 4. Dermaga Kayu di Desa Kedisan.

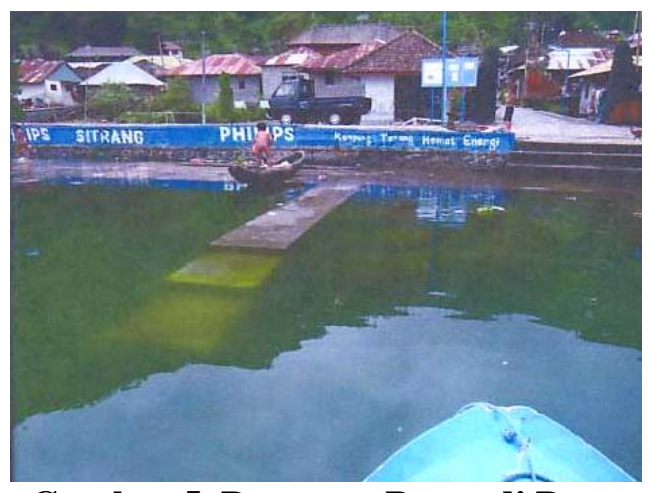

Gambar 5. Dermaga Beton di Desa Trunyan.

Selain itu, dermaga beton yang berada di kuburan Desa Trunyan kondisinya sama dengan yang ada di Desa Trunyan (lihat Gambar 6). Begitu pula dengan kondisi dermaga kayu yang berada di kuburan Desa Trunyan sudah tidak 
dapat dipergunakan lagi karena sudah rusak berat (lihat Gambar 7). Hal ini perlu mendapat perhatian untuk perbaikan mengingat dermaga kayu yang berada di depan kuburan Desa Trunyan selain untuk fasilitas pariwisata, dermaga ini dipergunakan oleh masyarakat Trunyan di saat ada upacara keagamaan (ngaben).

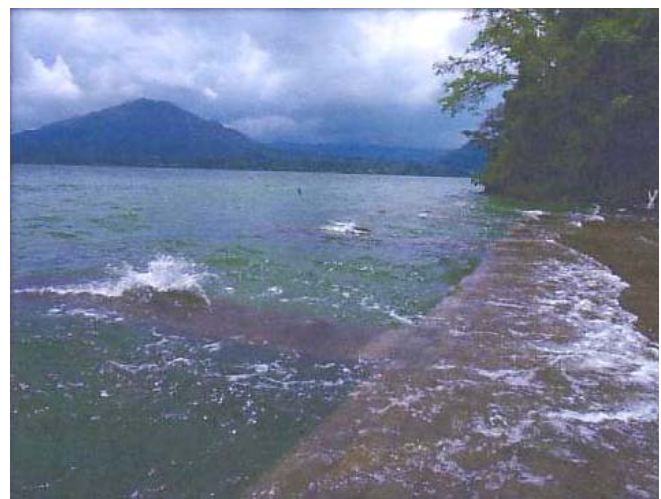

Gambar 6. Dermaga Beton di Kuburan Desa Trunyan.

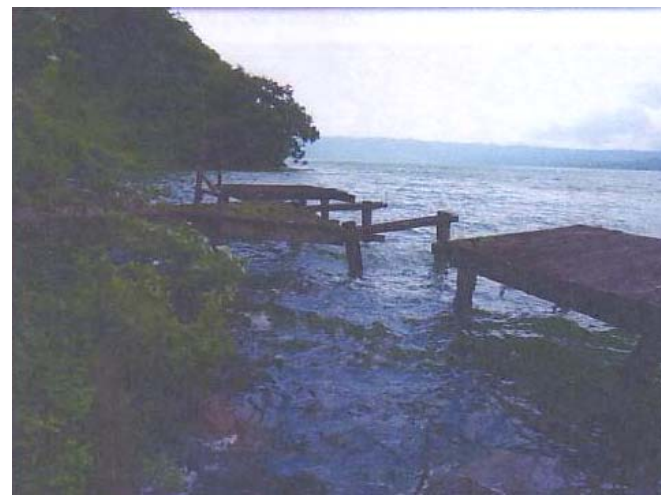

Gambar 7. Dermaga Kayu di Kuburan Desa Trunyan.

Tidak hanya kondisi beberapa dermaga di kawasan Danau Batur yang rusak, tetapi masih ada bangunan lainnya yang kondisinya sudah kurang baik, seperti ruang tunggu Dermaga Kedisan yang sudah tidak representatif (lihat Gambar 8), serta kondisi pos jaga di Desa Trunyan yang sudah rusak berat (lihat Gambar 5.9).

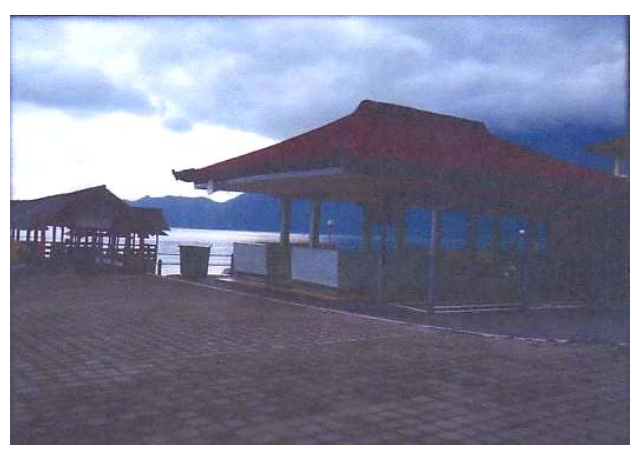

Gambar 8. Ruang Tunggu Dermaga

Kedisan.

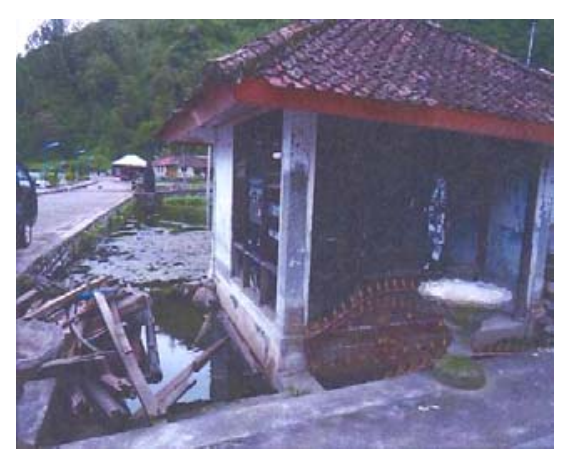

Gambar 9. Pos Jaga di Desa

Trunyan. 
Secara rinci, hasil pengamatan dan pengumpulan data yang diperoleh dari provinsi Sumatera Utara, Sumatera Selatan, Kalimantan Selatan, dan Bali, dapat dilihat pada Tabel 2.

Tabel 2. Hasil Pengamatan dan Pengumpulan Data.

\begin{tabular}{|c|l|c|c|c|c|}
\hline \multirow{2}{*}{ No. } & Nama Instansi & $\begin{array}{c}\text { Kordinasi } \\
\text { antar } \\
\text { instansi } \\
\text { terkait }\end{array}$ & $\begin{array}{c}\text { Pedoman } \\
\text { struktur } \\
\text { organisasi } \\
\text { dan tata } \\
\text { kerja }\end{array}$ & $\begin{array}{c}\text { Peraturan } \\
\text { setempat } \\
\text { yang } \\
\text { mendukung } \\
\text { kinerja } \\
\text { keselamatan }\end{array}$ & $\begin{array}{c}\text { Program } \\
\text { keselamatan } \\
\text { ASD }\end{array}$ \\
\hline 1 & Dishub Sumsel & Ada & Ada & Ada & Ada \\
\hline 2 & $\begin{array}{l}\text { Dishub } \\
\text { Palembang }\end{array}$ & Ada & Ada & Ada & Ada \\
\hline 3 & $\begin{array}{l}\text { STTD } \\
\text { Palembang }\end{array}$ & Ada & Ada & Ada & Ada \\
\hline 4 & Dishub Kalsel & Ada & Tidak ada & Tidak ada & Ada \\
\hline 5 & $\begin{array}{l}\text { Dishub } \\
\text { Banjarmasin }\end{array}$ & Ada & Ada & Ada & Ada \\
\hline 6 & Dishub Sumut & Ada & Ada & Ada & Ada \\
\hline 7 & $\begin{array}{l}\text { UPTD Ajibata } \\
\text { Kab. Tobasa }\end{array}$ & Ada & Ada (tidak & Ada & Ada \\
\hline 9 & Dishub Tabanan & Ada & Ada & Ada & Ada \\
\hline
\end{tabular}


Tabel 2. Hasil Pengamatan dan Pengumpulan Data (lanjutan).

\begin{tabular}{|c|c|c|c|c|c|}
\hline \multirow[b]{2}{*}{ No. } & \multirow[b]{2}{*}{$\begin{array}{l}\text { Nama } \\
\text { Instansi }\end{array}$} & \multicolumn{4}{|c|}{ Indikator } \\
\hline & & $\begin{array}{l}\text { Klasifikasi } \\
\text { data } \\
\text { kecelakaan }\end{array}$ & $\begin{array}{c}\text { Perizinan } \\
\text { lokasi } \\
\text { beroperasinya } \\
\text { kapal ASD }\end{array}$ & $\begin{array}{c}\text { Dana } \\
\text { keselamatan }\end{array}$ & $\begin{array}{l}\text { Kapal yang } \\
\text { memiliki } \\
\text { Jadwal dan } \\
\text { rute yang } \\
\text { tetap }\end{array}$ \\
\hline 1 & $\begin{array}{l}\text { Dishub } \\
\text { Sumsel }\end{array}$ & Ada & Ada & Ada & Ada \\
\hline 2 & $\begin{array}{l}\text { Dishub } \\
\text { Palembang }\end{array}$ & Ada & Ada & Ada & Ada \\
\hline 3 & $\begin{array}{l}\text { STTD } \\
\text { Palembang }\end{array}$ & Ada & Ada & Ada & Ada \\
\hline 4 & Dishub Kalsel & Ada & Ada & Ada & $\begin{array}{l}\text { Penyeberangan } \\
\text { ada, sungai } \\
\text { tidak ada }\end{array}$ \\
\hline 5 & $\begin{array}{l}\text { Dishub } \\
\text { Banjarmasin }\end{array}$ & Ada & Ada & Tidak ada & Ada \\
\hline 6 & $\begin{array}{l}\text { Dishub } \\
\text { Sumut }\end{array}$ & Tidak ada & Ada & Ada & Ada \\
\hline 7 & $\begin{array}{l}\text { UPTD } \\
\text { Ajibata } \\
\text { Kab. Tobasa }\end{array}$ & Tidak ada & Ada & Ada & Ada \\
\hline 8 & $\begin{array}{l}\text { Dishub } \\
\text { Tabanan }\end{array}$ & Tidak ada & Ada & Ada & Tidak ada \\
\hline 9 & $\begin{array}{l}\text { Dishub } \\
\text { Bangli }\end{array}$ & Tidak ada & Ada & Ada & Tidak ada \\
\hline
\end{tabular}


Tabel 2. Hasil Pengamatan dan Pengumpulan Data (lanjutan).

\begin{tabular}{|c|l|c|c|c|c|}
\hline \multirow{2}{*}{ No. } & \multirow{2}{*}{$\begin{array}{c}\text { Nama } \\
\text { Instansi }\end{array}$} & $\begin{array}{c}\text { Lintas } \\
\text { pelayaran }\end{array}$ & $\begin{array}{c}\text { Pedoman } \\
\text { penertiban dan } \\
\text { penataan } \\
\text { lingkungan }\end{array}$ & $\begin{array}{c}\text { Pengendalian } \\
\text { fungsi alur } \\
\text { sungai }\end{array}$ & $\begin{array}{c}\text { Pengendalian } \\
\text { kegiatan tepi } \\
\text { sungai/danau }\end{array}$ \\
\cline { 3 - 7 } & $\begin{array}{c}\text { Dishub } \\
\text { Sumsel }\end{array}$ & $\begin{array}{c}\text { Pergi- } \\
\text { Pulang (pp) }\end{array}$ & Tidak ada & Kurang & Kurang sekali \\
\hline 2 & $\begin{array}{l}\text { Dishub } \\
\text { Palembang }\end{array}$ & $\begin{array}{c}\text { Pergi- } \\
\text { Pulang (pp) }\end{array}$ & Tidak ada & Kurang & Kurang sekali \\
\hline 3 & $\begin{array}{l}\text { STTD } \\
\text { Palembang }\end{array}$ & $\begin{array}{c}\text { Pergi- } \\
\text { Pulang (pp) }\end{array}$ & Tidak ada & Kurang & Kurang sekali \\
\hline 4 & $\begin{array}{l}\text { Dishub } \\
\text { Kalsel }\end{array}$ & $\begin{array}{c}\text { Pergi- } \\
\text { Pulang (pp) }\end{array}$ & Tidak ada & Kurang & Tidak ada \\
\hline 5 & $\begin{array}{l}\text { Dishub } \\
\text { Banjarmasin }\end{array}$ & $\begin{array}{c}\text { Pergi- } \\
\text { Pulang (pp) }\end{array}$ & Ada & Kurang & Tidak ada \\
\hline 6 & $\begin{array}{l}\text { Dishub } \\
\text { Sumut }\end{array}$ & $\begin{array}{c}\text { Pergi- } \\
\text { Pulang (pp) }\end{array}$ & Tidak ada & Kurang & Kurang sekali \\
\hline 7 & $\begin{array}{l}\text { UPTD } \\
\text { Ajibata } \\
\text { Kab. Tobasa }\end{array}$ & $\begin{array}{l}\text { Pergi- } \\
\text { Pulang (pp) }\end{array}$ & Tidak ada & Kurang & Kurang sekali \\
\hline 9 & $\begin{array}{l}\text { Dishub } \\
\text { Bangli }\end{array}$ & $\begin{array}{c}\text { Ppanan } \\
\text { pp dan rit }\end{array}$ & Tidak ada & Kurang & Kurang \\
\hline
\end{tabular}


Tabel 2. Hasil Pengamatan dan Pengumpulan Data (lanjutan).

\begin{tabular}{|c|c|c|c|c|c|}
\hline \multirow[b]{2}{*}{ No. } & \multirow[b]{2}{*}{$\begin{array}{c}\text { Nama } \\
\text { Instansi }\end{array}$} & \multicolumn{4}{|c|}{ Indikator } \\
\hline & & $\begin{array}{c}\text { Standar } \\
\text { perlengkapan } \\
\text { keselamatan }\end{array}$ & $\begin{array}{c}\text { Kapal yang } \\
\text { beroperasi } \\
\text { sudah } \\
\text { memenuhi } \\
\text { standar } \\
\text { kelaikan }\end{array}$ & $\begin{array}{c}\text { Prosedur dan } \\
\text { manual uji } \\
\text { berkala dan } \\
\text { uji tipe }\end{array}$ & $\begin{array}{c}\text { Pemeriksaan } \\
\text { terhadap } \\
\text { kepatuhan } \\
\text { pengoperasian } \\
\text { kapal }\end{array}$ \\
\hline 1 & $\begin{array}{l}\text { Dishub } \\
\text { Sumsel }\end{array}$ & Ada & Ya & Ada & $\begin{array}{l}\text { Ada, tanpa } \\
\text { sanksi }\end{array}$ \\
\hline 2 & $\begin{array}{l}\text { Dishub } \\
\text { Palembang }\end{array}$ & Ada & Ya & Ada & $\begin{array}{l}\text { Ada, tanpa } \\
\text { sanksi }\end{array}$ \\
\hline 3 & $\begin{array}{l}\text { STTD } \\
\text { Palembang }\end{array}$ & Ada & Ya & Ada & $\begin{array}{l}\text { Ada, tanpa } \\
\text { sanksi }\end{array}$ \\
\hline 4 & $\begin{array}{l}\text { Dishub } \\
\text { Kalsel }\end{array}$ & $\begin{array}{l}\text { Ada, belum } \\
\text { terealisasi }\end{array}$ & Ya & Ada & $\begin{array}{l}\text { Ada, tanpa } \\
\text { sanksi }\end{array}$ \\
\hline 5 & $\begin{array}{l}\text { Dishub } \\
\text { Banjarmasin }\end{array}$ & Ada & Ya & Ada & $\begin{array}{l}\text { Ada, tanpa } \\
\text { sanksi }\end{array}$ \\
\hline 6 & $\begin{array}{l}\text { Dishub } \\
\text { Sumut }\end{array}$ & Ada & Ya & Ada & $\begin{array}{l}\text { Ada, tanpa } \\
\text { sanksi }\end{array}$ \\
\hline 7 & $\begin{array}{l}\text { UPTD } \\
\text { Ajibata } \\
\text { Kab. Tobasa }\end{array}$ & Ada & Ya & Tidak ada & $\begin{array}{l}\text { Ada, tanpa } \\
\text { sanksi }\end{array}$ \\
\hline 8 & $\begin{array}{l}\text { Dishub } \\
\text { Tabanan }\end{array}$ & Ada & Ya & Ada & $\begin{array}{l}\text { Ada, tanpa } \\
\text { sanksi }\end{array}$ \\
\hline 9 & $\begin{array}{l}\text { Dishub } \\
\text { Bangli }\end{array}$ & Ada & Ya & Ada & $\begin{array}{l}\text { Ada, tanpa } \\
\text { sanksi }\end{array}$ \\
\hline
\end{tabular}


Tabel 2. Hasil Pengamatan dan Pengumpulan Data (lanjutan).

\begin{tabular}{|c|c|c|c|c|c|}
\hline \multirow[b]{2}{*}{ No. } & \multirow{2}{*}{$\begin{array}{l}\text { Nama } \\
\text { Instansi }\end{array}$} & \multicolumn{4}{|c|}{ Indikator } \\
\hline & & $\begin{array}{c}\text { Pemeriksaan } \\
\text { perlengkapan } \\
\text { keselamatan }\end{array}$ & $\begin{array}{c}\text { Standar } \\
\text { masa layan } \\
\text { kapal }\end{array}$ & $\begin{array}{l}\text { Surat ijin } \\
\text { berlayar }\end{array}$ & $\begin{array}{l}\text { Pemeriksaan } \\
\text { thd penumpang }\end{array}$ \\
\hline 1 & $\begin{array}{l}\text { Dishub } \\
\text { Sumsel }\end{array}$ & Ada & Tidak ada & $\begin{array}{c}\text { Ada: Surat } \\
\text { Keterangan } \\
\text { Kecakapan } \\
\text { Kapal } \\
\text { Pedalaman / } \\
\text { SKKKP }\end{array}$ & $\begin{array}{l}\text { Ada, tanpa } \\
\text { sanksi }\end{array}$ \\
\hline 2 & $\begin{array}{l}\text { Dishub } \\
\text { Palembang }\end{array}$ & Ada & Tidak ada & $\begin{array}{c}\text { Ada: } \\
\text { SKKKP }\end{array}$ & $\begin{array}{l}\text { Ada, tanpa } \\
\text { sanksi }\end{array}$ \\
\hline 3 & $\begin{array}{l}\text { STTD } \\
\text { Palembang }\end{array}$ & Ada & Tidak ada & $\begin{array}{c}\text { Ada: } \\
\text { SKKKP }\end{array}$ & $\begin{array}{l}\text { Ada, tanpa } \\
\text { sanksi }\end{array}$ \\
\hline 4 & $\begin{array}{l}\text { Dishub } \\
\text { Kalsel }\end{array}$ & $\begin{array}{l}\text { Ada, operator } \\
\text { masih kurang } \\
\text { patuh }\end{array}$ & Tidak ada & $\begin{array}{l}\text { Ada: STK } \\
\text { (Surat Tanda } \\
\text { Kecakapan) }\end{array}$ & $\begin{array}{l}\text { Ada, tanpa } \\
\text { sanksi }\end{array}$ \\
\hline 5 & $\begin{array}{l}\text { Dishub } \\
\text { Banjarmasin }\end{array}$ & Ada & Tidak ada & Ada: STK & $\begin{array}{l}\text { Ada, tanpa } \\
\text { sanksi }\end{array}$ \\
\hline 6 & $\begin{array}{l}\text { Dishub } \\
\text { Sumut }\end{array}$ & Tidak ada & Tidak ada & Ada & Tidak ada \\
\hline 7 & $\begin{array}{l}\text { UPTD } \\
\text { Ajibata } \\
\text { Kab. Tobasa }\end{array}$ & Tidak ada & Tidak ada & Ada & Tidak ada \\
\hline 8 & $\begin{array}{l}\text { Dishub } \\
\text { Tabanan }\end{array}$ & Ada & Tidak ada & Ada: STK & $\begin{array}{l}\text { Ada, tanpa } \\
\text { sanksi }\end{array}$ \\
\hline 9 & $\begin{array}{l}\text { Dishub } \\
\text { Bangli }\end{array}$ & Ada & Tidak ada & Ada: STK & $\begin{array}{l}\text { Ada, tanpa } \\
\text { sanksi }\end{array}$ \\
\hline
\end{tabular}


Tabel 2. Hasil Pengamatan dan Pengumpulan Data (lanjutan).

\begin{tabular}{|c|l|c|c|}
\hline \multirow{2}{*}{ No. } & \multirow{2}{*}{ Nama Instansi } & \multicolumn{2}{|c|}{ Indikator } \\
\cline { 3 - 4 } & & Pos gawat darurat & $\begin{array}{c}\text { Santunan PT Jasa } \\
\text { Raharja }\end{array}$ \\
\hline 1 & Dishub Sumsel & Tidak ada & Ada \\
\hline 2 & Dishub Palembang & Tidak ada & Ada \\
\hline 3 & STTD Palembang & Tidak ada & Ada \\
\hline 4 & Dishub Kalsel & Tidak ada & Ada \\
\hline 5 & Dishub Banjarmasin & Tidak ada & Ada \\
\hline 6 & Dishub Sumut & Tidak ada & Ada \\
\hline 7 & UPTD Ajibata Kab. & Tidak ada & Ada \\
\hline 8 & Dishub Tabanan & Tidak ada & Ada \\
\hline 9 & Dishub Bangli & Tidak ada & \multicolumn{2}{|c|}{} \\
\hline
\end{tabular}

\subsection{Pembahasan}

Berdasarkan hasil survei dan pengumpulan data terkait angkutan sungai di Provinsi Sumatera Utara, dapat dianalisis secara aspek manajemen keselamatan, prasarana (sungai dan danau), sarana (kapal), SDM dan pengguna angkutan sungai dan danau, serta penanganan pasca kecelakaan, antara lain sebagai berikut:

\section{a. Aspek Manajemen Keselamatan}

1) Kordinasi antar instansi terkait keselamatan ASD sudah ada, tetapi belum maksimal. Oleh karena itu perlu adanya suatu wadah/media (misalnya berupa forum) untuk mengatasi bersama antar instansi terkait keselamatan ASD.

2) Pedoman struktur organisasi dan tata kerja sudah ada. Oleh karena itu perlu dipertahankan, bila perlu ditingkatkan lagi. 
3) Peraturan-peraturan setempat yang mendukung kinerja keselamatan sudah ada, dengan mengacu pada Peraturan Daerah setempat. Hal ini perlu direalisasikan secara bijak di lapangan.

4) Program keselamatan ASD seperti sosialisasi perambuan sudah ada, yaitu dilakukan pada operator-operator kapal. Bila perlu lebih ditingkatkan lagi.

5) Klasifikasi/jenis data kecelakaan tidak ada. Perlu dipikirkan bersama, baik oleh pemerintah pusat maupun pemerintah daerah setempat untuk membentuk suatu organisasi guna pencatatan informasi/data kecelakaan yang terklasifikasi secara jelas.

6) Perizinan lokasi dan operasi rute berdasarkan trayek masing-masing kapal. Hal ini perlu ditingkatkan lagi.

7) Adanya peraturan/kebijakan kegiatan ASD setempat yang mengakomodir aspek keselamatan.

8) Kapal yang memiliki jadwal keberangkatan dan kedatangan dengan rute tetap sudah ada, dengan lintas pelayaran kapal adalah pergi-pulang (pp). Hal ini perlu dipertahankan dan bila perlu lebih ditingkatkan lagi.

9) Sejak adanya otonomi daerah dimana peralihan kewenangan ASD dari pemerintah pusat ke pemerintah daerah menyebabkan manajemen keselamatan ASD kurang terkordinasi secara maksimal. Hal ini perlu ditangani lebih serius oleh pemerintah daerah maupun pemerintah pusat.

\section{b. Aspek Prasarana}

1) Dana keselamatan untuk penigkatan dan pemeliharaan prasarana ASD pemerintah sudah ada. Akan tetapi kenyataannya kondisi ASD yang ada masih memprihatinkan, oleh karena itu dana keselamatana perlu ditingkatkan lagi demi lebih terjaminnya keselamatan penumpang ASD.

2) Pedoman penertiban dan penataan lingkungan sungai terkait keselamatan tidak ada. Oleh karena itu perlu dibuatnya suatu pedoman penertiban dan penataan lingkungan sungai terkait keselamatan oleh pemerintah pusat atau pemerintah daerah setempat.

3) Pengendalian fungsi alur sungai termasuk perambuan lalu lintas sungai masih kurang terpenuhi. Oleh karena itu perlu ditingkatkan lagi melalui koordinasi antara pemerintah pusat dan pemerintah daerah. 
4) Pengendalian kegiatan tepi sungai masih kurang terpenuhi. Oleh karena itu perlu ditingkatkan lagi melalui koordinasi antar instansi terkait baik dari pemerintah pusat maupun pemerintah daerah.

\section{c. Aspek Sarana}

1) Perlengkapan keselamatan seperti pelampung sudah ada. Meskipun demikian perlu juga diperhatikan kondisi kelaikan perlengkapan keselamatan tersebut dan juga perlu disosialisasikan kepada penumpang ASD.

2) Standar kelaikan kapal meliputi kapasitas mesin terkait dengan klasifikasi dimensi kapal dalam prosedur sertifikasi kelaikan kapal dan mesin disesuaikan dengan keadaan badan kapalnya. Hal ini harus dipertahankan dan bila perlu ditingkatkan lagi.

3) Prosedur uji berkala dan uji tipe bagi kapal yang beroperasi sudah ada. Hal ini harus direalisasikan secara bijak di lapangan dan bila perlu lebih ditingkatkan lagi.

4) Pemeriksaan terhadap kepatuhan pengoperasian kapal selalu diawasi dan diperiksa. Akan tetapi kenyataannya di lapangan masih kurang terlaksana. Oleh karena itu, bagi kapal yang melanggar harus ditindak dengan tegas.

5) Petugas Dishub melakukan pengawasan meliputi perlengkapan berlayar. Hal ini harus dipertahankan dan bila perlu ditingkatkan lagi.

6) Standar untuk masa layan kapal belum ada. Oleh karena itu perlu dibuatnya suatu standar legalitas yang mengatur masa layan kapal. Hal ini guna tetap terjaganya kondisi kelaikan kapal.

\section{d. Aspek SDM dan Pengguna ASD}

1) Standar untuk awak kapal (juru mudi) sudah ada, yaitu berupa STK (Surat Tanda Kecakapan) atau Surat Keterangan Kecakapan Kapal Pedalaman (SKKKP). Meskipun demikian, perlu dilakukannya pemeriksaan oleh petugas kepada para awak kapal untuk memastikan bahwa awak kapal benar-benar profesional dalam mengoperasikan kapal.

2) Pemeriksaan kesehatan bagi awak kapal dalam bentuk diberi surat kesehatan kepada Pemda. Meskipun demikian perlu ditingkatkan lagi secara lebih intensif. 
3) Pemeriksaan bagi penumpang yang melanggar peraturan selalu dilakukan kepada setiap penumpang. Hal ini harus benar-benar direalisasikan di lapangan dan tindakan yang tegas, bila perlu diberi sanksi bagi yang melanggar.

\section{e. Penanganan Pasca Kecelakaan ASD}

a. Pos gawat darurat maupun Standar Prosedur Operasional (SPO) kegawatdaruratan kecelakaan belum ada. Hal ini perlu dipikirkan serius oleh pemerintah pusat maupun daerah untuk menyediakan pos gawat darurat.

b. Santunan biaya pengobatan kepada korban kecelakaan ASD sudah ada, dari PT. Jasa Raharja. Hal ini harus dipertahankan dan bila perlu lebih ditingkatkan lagi.

\section{PENUTUP}

\subsection{Kesimpulan}

Dari hasil pengamatan di provinsi Sumatera Utara, Sumatera Selatan, Kalimantan Selatan, dan Bali, ternyata tiap wilayah telah mempunyai Perda dan peraturan lokal untuk menanggulangi bahaya kecelakaan angkutan sungai dan danau dengan istilah teknik yang berbeda, kedalaman dan keluasan peraturan termasuk perizinan yang berbeda pula. Di sisi yang lain mempunyai orientasi yang sama bahwa dalam hal perizinan angkutan sungai dan danau (ASD) merupakan PAD (Pendapatan Asli Daerah) sehingga ketegasan dalam penerapan keselamatan ASD menjadi lemah, seperti penggunaan baju pelampung, alat navigasi, dan lain-lain.

\subsection{Saran}

1. Perlu dilakukannya sosialisasi tentang pentingnya keselamatan angkutan sungai dan danau, baik kepada awak kapal, penumpung kapal, maupun operator,

2. Untuk mendukung keselamatan angkutan sungai dan danau, perlu adanya Pedoman Umum Keselamatan Angkutan Sungai dan Danau sebagai pedoman bagi pemerintah untuk mengatasi masalah keselamatan di Indonesia terutama di daerah terpencil. Selain itu, penyusunan Pedoman 
Umum Keselamatan Angkutan Sungai dan Danau dilakukan dikarenakan belum adanya persamaan persepsi terhadap keselamatan di daerah serta penangangan masalah keselamatan tersebut masih dilakukan secara parsial dan belum terkoordinasi dengan baik sehingga masalah keselamatan tersebut belum dapat tertangani secara komprehensif.

\section{DAFTAR PUSTAKA}

1. Badan Pusat Statistik Provinsi Bali (2012). “Bali Dalam Angka Tahun 2012”, Denpasar.

2. Badan Pusat Statistik Provinsi Kalimantan Selatan (2012). "Kalimantan Selatan Dalam Angka Tahun 2012”, Banjarmasin.

3. Dinas Perhubungan, Komunikasi dan Informasi Kota Banjarmasin (2012). "Laporan Akhir: Inventarisasi, Evaluasi dan Pengembangan Dermaga”, Banjarmasin.

4. Dinas Perhubungan, Komunikasi dan Informasi Provinsi Sumatera Selatan (2013). “Informasi Bidang Perhubungan Laut ASDP”, Palembang.

5. Dinas Perhubungan, Komunikasi dan Informasi Provinsi Sumatera Utara (2006). “Laporan Akhir: Survey Asal Tujuan Kapal di Kawasan Danau Toba (O/D Survey)”, Medan.

6. Direktorat Jenderal Perhubungan Darat (2009). "Perhubungan Darat Dalam Angka 2008”, Jakarta.

7. Direktorat Keselamatan Transportasi Darat (2013). "Laporan Akhir: Penyusunan Rencana Umum Keselamatan Angkutan Sungai Dan Danau”, Jakarta.

8. Pemerintah Republik Indonesia (2007). "Peraturan Pemerintah Nomor 38 Tahun 2007 Tentang Pembagian Urusan Pemerintahan Antara Pemerintah, Pemerintahan Daerah Provinsi, dan Pemerintahan Daerah Kabupaten/Kota”, Jakarta.

9. Pemerintah Republik Indonesia (2008). “Undang-Undang Republik Indonesia Nomor 17 Tahun 2008 Tentang Pelayaran”, Jakarta. 
10. Pemerintah Republik Indonesia (2010). "Peraturan Pemerintah Nomor 20 Tahun 2010 Tentang Angkutan Di Perairan”, Jakarta.

11. Pemerintah Republik Indonesia (2010). "Peraturan Pemerintah Nomor 5 Tahun 2010 Tentang Kenavigasian”, Jakarta. 